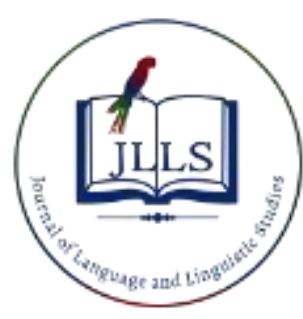

Available online at www.jlls.org

\section{JOURNAL OF LANGUAGE} AND LINGUISTIC STUDIES

ISSN: $1305-578 \mathrm{X}$

Journal of Language and Linguistic Studies, 16(2), 738-756; 2020

\title{
Impact of bilingual practice on EFL learners' self-efficacy
}

\author{
Stefan Rathert $^{\text {a (D) }}$, Neşe Cabaroğlu ${ }^{\text {b } 1}$ \\ ${ }^{a}$ Kahramanmaras Sütçü Imam University, Kahramanmaraş, Turkey \\ ${ }^{b}$ Çukurova University, Adana, Turkey

\section{APA Citation:}

Rathert,S., \& Cabaroğlu, N. (2020). Impact of bilingual practice on EFL learners' self-efficacy. Journal of Language and Linguistic Studies, 16(2), 738-756

Submission Date: 20/12/2019

Acceptance Date: $18 / 05 / 2020$

\begin{abstract}
Acknowledging the increased appreciation of the learner's L1 for L2 learning, this study reports on a criteria-based implementation of bilingual activities in a course of 26 young adult EFL learners at a Turkish university. To investigate potential effects of the bilingual practice on the learners' self-efficacy, a self-efficacy scale of English was administered before and after the 14-week course. Interviews were conducted to triangulate the results of the comparative analysis of the self-efficacy scale. The analysis revealed that only five out of 25 students' self-efficacy perceptions (related to speaking and writing) changed significantly with moderate effect size. The findings from the interviews suggest that changes in self-efficacy were only partly associated with the implementation of bilingual activities, and that unfavourable conditions of the course context overshadowed potential positive effects of the bilingual practice. However, the results also indicate that the bilingual practice was perceived conducive to L2 learning and that it may serve as a tool to addresses the specific needs of learners with diminished self-efficacy.
\end{abstract}

C 2020 JLLS and the Authors - Published by JLLS.

Keywords: Bilingual practice; self-efficacy; English as a foreign language; methodology; young adult learners

\section{Introduction}

There has been a growing attention towards the role of the learner's own or first language (L1) to teach a foreign or second language (L2) for about a quarter century (Kerr, 2015). Research on L1 use in L2 classrooms demonstrates various communicative and pedagogic functions of L1 (Anton \& DiCamilla, 1999; Cook, 2018; Hall \& Cook, 2012, 2013; Swain \& Lapkin, 2000). Particularly, the potential of L1 as contributing to a dual clarification of meaning and grammatical structure has been emphasized (Ammar, Lightbown \& Spada, 2010). While L2-only approaches reflect a form of linguistic oppression because the L1 is stigmatized as unwelcome in the L2 classroom (Auerbach, 1993), L1 inclusion is considered to generate a sense of belonging and confidence in learners (Brooks-Lewis, 2009; Macaro, Nakatani, Hayashi \& Khabbazbashi, 2014). The translingual practice of bilingual (or multilingual) speakers in communication and language learning gives additional evidence for the role of the learner's L1 as a learning resource (May, 2014; Moore, 2018).

\footnotetext{
${ }^{1}$ Corresponding author. Tel.: +0-533-622-0652

E-mail address: ncabar@cu.edu.tr
} 
Littlewood and $\mathrm{Yu}$ (2011) propose a framework for a principled teacher-initiated L1 use in the L2 classroom according to which L1 can be utilized to reach core goals, i.e. to teach L2, or framework goals, i.e. to serve classroom management. To address these goals, L1 can be employed as a strategic device in form of planned bilingual practice or as an ad hoc response to emerging difficulties. Hence, L1 inclusion in L2 classrooms can be realized following a weak bilingual approach which principally accepts occurrence of L1 in L2 teaching as inevitable or justifiable for specific reasons or as a systematic implementation through deployment of "sophisticated and powerful bilingual techniques necessary to harness the linguistic resources of the learners for effective foreign language learning" (Butzkamm \& Caldwell, 2009, p. 16).

In spite of the scholarly support for bilingual practice, classroom-based research on deliberate exploitations of L1 to teach L2 is scarce (Ellis \& Shintani, 2014), and an expansion of the contextdependent knowledge base is desirable (Lee, 2018; Scheffler, Hoverak, Krzebietke \& Askland, 2017). This paper addresses this research gap by reporting on part of a study investigating a criteria-based inclusion of bilingual activities in a compulsory EFL (English as a foreign language) course for Turkish university students. Courses in this context frequently suffer from students' indifference towards learning English based on unclear perspectives on the relevance of English learning (British Council, 2015). Taking this context into consideration and given the claim that L1 inclusion provides "rewards of mastery: a sense of competence and control" (Butzkamm \& Caldwell, 2009, p. 171), effects of bilingual practice on learner self-efficacy perceptions were examined. Self-efficacy was taken as an indicator because it is a psychological construct which is particularly sensitive to the design of instructional practice, and its enhancement "ensure[s] that learners feel competent and capable in their ability to acquire a FL [foreign language]" (Mills, 2014, p. 19).

\subsection{Literature review}

\subsubsection{Bilingual approach}

A re-evaluation of the learners' L1 in L2 acquisition has posed a serious challenge to practices following a monolingual approach (Levine, 2013). Traceable to the Direct Method as a response to the prevailing Grammar Translation at the end of the $19^{\text {th }}$ century, monolingualism has been explicitly or implicitly the valid paradigm in many of the divergent approaches and methods since then (Littlewood \& Yu, 2011; Mahboob \& Lin, 2016). The monolingual approach assumes that L2 is best taught exclusively through L2 by native-speaker teachers, effective L2 learning resembles L1 acquisition and learners need to reach a native speaker-like competence (G. Cook, 2010). However, these assumptions and views that L1 use reduces the time available for L2, prevents learners from thinking in L2, and L1 interferes with L2 so that the languages should be kept separated are no longer supported unanimously (Ellis \& Shintani, 2014).

The postulated superiority of monolingual practice has been challenged from different perspectives. For one thing, the idea that L1 can somehow be switched off in a learner's mind by separating L1 and L2 is rejected. Instead, V. Cook (2010) proposes an "integrative continuum" (p. 148) with language areas integrated or separated to different extent in an individual. Additionally, the L1 as "an indispensable Language Acquisition Support System" (Butzkamm \& Caldwell, 2009, p. 66), provides learners with an awareness of the symbolic function of language, knowledge of grammatical concepts, pragmatic competence, and literary skills. Furthermore, research grounded in socio-cultural learning theory refers to the mediating role L1 plays in the L2 classroom as it "accomplishes beneficial cognitive, social, and affective functions for learners attempting to become bilingual" (DiCamilla \& Anton 2012, p. 168) by allowing learners to negotiate meaning, reduce cognitive overload, express feelings and engage in classroom discourse (e.g. Alegria de la Colina \& Garcia Mayo, 2009; Bruen \& Kelly, 2017; Ganem-Gutierrez \& Roehr, 2011; He, 2012; Moore, 2013; Ziegler, Sert \& Durus, 2012). This is 
supported by reports on learner perceptions: In Brooks-Lewis' (2009) study, for example, learners emphasized that L1 inclusion enabled them to follow classroom activities as they anchored L2 into existing knowledge (i.e. L1) through noticing differences and similarities. The author concludes that banning the learners' L1 can deprive learners of a part of their identity and cause disorientation, anxiety and alienation (cf. Neokleous, 2017).

More recently, the notion of translingualism, encompassing many of the arguments given above, has given further support for the re-conceptualization of the L2 classroom as a bilingual (or multilingual) environment. Informed by the linguistic behavior of bilingual speakers in non-educational and school contexts (Cohen, 2015), the term refers to bilinguals' practices "of accessing different linguistic features or various modes of what are described as autonomous languages, in order to maximize communicative potential" (Garcia, 2009, p. 140). Replacing structuralist conceptualizations, language is viewed "as an integrated, crosslingual, dynamic and multimodal semiotic system" (Meier, 2017, p. 135, emphasis added) owned by individual speakers.

The obvious implication for the L2 classroom is to conceptualize L2 learners as "emergent bilinguals" (Turnbull, 2016, p. 1) who enrich their linguistic system through adding an L2 to their already existing L1 (Cummins, 2017). This conceptualization encompasses an appreciation of the L2 classroom as a genuinely bilingual space where learners have two languages available at different proficiency levels (Canagarajah, 2018) and an invalidation of the monolingual bias postulating nativelike competence as the overarching aim of L2 learning (V. Cook, 2010). Even though this conceptualization resonates with the Common European Framework of Reference for Languages (CEFR) which acknowledges the value of a bilingual's "plurilingual and pluricultural competence" (Council of Europe, 2001, p.135), L2 teachers reportedly use L1 rather as a remedy for faced problems than systematically as a strategic tool (Levine, 2013). This reluctance is due to prevailing monolingual language learning pedagogies and policies, along with teachers' unawareness of or reservations against bilingual practices available (Martínez, Hikida \& Durán, 2015; Meier, 2017; Turnbull, 2016; Wang, 2016).

\subsubsection{Bilingual practice}

Bilingual practice in the form of activities that integrate the $\mathrm{L} 1$ in learning tasks have been introduced in a variety of teacher-oriented publications (e.g. Butzkamm \& Caldwell, 2009; G. Cook, 2010; Deller \& Rinvolucri, 2002; Gonzales Davies, 2004; Kerr, 2014; Laviosa, 2014; Leonardi, 2010). Designed not to replace monolingual instruction but to enrich the array of classroom techniques, many activities are applicable in multilingual classes and do not require the teacher's knowledge of the learners' L1.

Bilingual activities address different language domains and skills. Grammar-focused activities typically include contrastive form-focused instruction to clarify meaning and form of grammar points (Ammar, Lightbown \& Spada, 2010; Butzkamm, 2001; Kupferberg, 1999; Kupferberg \& Olshtain, 1996). Bilingual vocabulary teaching covers areas like homonyms, collocations, abstract words and clarification of socio-pragmatic aspects of lexical items (Augustyn, 2013; Laufer \& Girsai, 2008; Tian \& Macaro, 2012). In receptive and productive skills work, recourse to L1 may be realized through reporting in L1 what has been understood from an L2 text or using L1 sources to prepare for L2 language production (Anderson, 2018; Kim, 2011; Macaro, 2005). Fallen into disrepute due to its closeness to the Grammar Translation method (G. Cook, 2010), translation has been re-appreciated as a real-world activity engaging learners in simultaneously focusing on grammar, vocabulary and pragmatics (Corcoll Lopez \& Gonzales-Davies, 2016; Kelly \& Bruen, 2015; Lee, 2018; Leonardi, 2010).

Obviously, bilingual practice contributes to L2 learners' translingual competence, which may well correspond to language learners' real or assumed future language use (Anderson, 2018). Contrary to expressed concerns (Paquet-Gauthier \& Beaulieu, 2016), it also prepares learners for monolingual 
contexts as many activities are designed to facilitate L2 acquisition or lead into monolingual practice (Butzkamm \& Caldwell, 2009).

\subsubsection{Self-efficacy}

Self-efficacy refers to an individual's judgment of his/her own ability to achieve a specific task in a certain domain (Bandura, 1997). Based on Bandura's $(1986,1997)$ social cognitive theory, humans are conceptualized as proactive, self-reflective and self-regulating rather than solely receptive and responding to external stimuli as they rely on a system of self-beliefs (Bandura, 2001; Pajares, 2002). According to the theory, human functioning is realized in a triadic reciprocal interplay between personality, environment and behavior indicating that humans are both producers and products of social systems. Social cognitive theory also emphasizes the role of the mental representation of experiences for shaping acting and of self-reflection for assessing own beliefs and actions to possibly modify them (Bandura, 1986, 1997).

Of central importance for self-reflection is self-efficacy. Unlike other adjacent self constructs (Mills, 2014), self-efficacy beliefs are "specific cognitive expectations for personal mastery of specified upcoming achievement tasks" (Rivers \& Ross, 2018, p. 2). Individuals generate, strengthen or lower self-efficacy by analyzing information gained through experiencing own performance (mastery experiences), observing other individuals' performances (vicarious experiences), receiving verbal judgments (verbal persuasion) and experiencing somatic and emotional states during task completion (physiological states) (Bandura, 1997). Informed through these four sources, people develop selfefficacy beliefs which "become instrumental to the goals they pursue and to the control they are able to exercise over their environment" (Pajares, 2002, p. 116). Learners with enhanced self-efficacy undertake tasks with more effort, persistence and intrinsic motivation, feel less anxious, exert self-regulation and evaluate own performance more accurately (Mills, 2014; Mills, Pajares \& Heron, 2006). However, increased self-efficacy is unlikely to be transformed directly into action unless self-efficacy beliefs realistically correspond with actual capabilities or task outcomes are perceived as valuable (Rivers \& Ross, 2018). Current models of motivation recognize the interdependence of self-efficacy with other factors. Kormos, Kiddle and Csizér (2011), for instance, locate self-efficacy in a set of self-guides, which are informed by the instructional and wider social context and stand in bidirectional relation to goals and motivational behavior.

As learner self-efficacy is promoted through cognitive processes, the design of instructional practices is essential for its enhancement (Keller, 1979; Mills, 2014). Related research has been inspired by Graham (2007) examining the influence of listening strategy training and feedback and Graham and Macaro (2008) investigating impacts of listening strategy training on listening self-efficacy; both studies revealed enhancement of a range of listening self-efficacy beliefs. Other studies reported effects of strategy and self-regulation on writing self-efficacy (Ching, 2002), metacognitive strategy instruction on listening self-efficacy (Rahimirad \& Zare-ee, 2015), language learning strategies on self-efficacy beliefs related to motivation (Yang \& Wang, 2015), concept mapping instruction on English learning self-efficacy (Chularut \& DeBacker, 2004; Khajavi \& Ketabi, 2012), cooperative learning instruction on English learning self-efficacy (Pan \& Wu, 2013) and listening strategy use on listening self-efficacy (Taki \& Esmaeili, 2017). The implementation of self-assessment techniques were shown to exert significant effects on self-efficacy (Alishah \& Dolmaci, 2013; Baleghizadeh \& Masoun, 2013), and Ruegg (2018) reports a significantly higher impact of teacher feedback on EFL university students' writing self-efficacy than peer feedback. Other studies, frequently incorporating strategy training, indicate impacts of technological innovations on self-efficacy (Huang \& Yang, 2015; Tai, 2016; Yang, Guo \& Yu, 2016). Instruction using virtual environments (Henderson, Huang, Grant \& Henderson, 2012; Mills \& Péron, 2009; Xu, Park \& Baek, 2011; Zhen, Young, Brewer \& Wagner, 2009) or podcasts (Başaran \& Cabaroğlu, 2014) document effects on self-efficacy perceptions. While the majority of 
studies were conducted in tertiary education, Rachels and Rockinson-Szapkiw (2018) report that gamification did not reveal statistically significant changes on young learners' academic self-efficacy beliefs.

Another strand of research examined instructional design addressing the cognitive and emotional dispositions of learners: While Oghyanous (2017) for brain-based teaching and Balci (2017) for learning style oriented teaching showed impacts, Scida and Jones (2017) did not reveal any statistically significant differences between pre- and post-test or experimental and control group in self-efficacy beliefs related to stress management of university students receiving contemplative practices.

Three studies used classroom practices deliberately tailored to enhance learner self-efficacy. Mills (2009) investigated the influence of project-based learning revealing enhanced learner self-efficacy concerning interaction, exchanging opinions, interpreting texts, integrating new information, and communicating cultural issues. Learners in Moreno and Kilpatrick's (2018) longitudinal qualitative study report that their self-efficacy concerning productive skills and task autonomy had increased due to flipped classroom applications. Finally, in EFL learners using self-efficacy building strategies, selfefficacy and motivation improvement were positively correlated with strategy use frequency, and motivation with self-efficacy (Cave, Evans, Dewey \& Hartshorn, 2018)

In sum, research indicates that various instructional interventions influence learner self-efficacy beliefs to changing extent. To the best of our knowledge, no study has examined impacts of bilingual practice on L2 learner self-efficacy of English.

\section{Method}

\subsection{Rationale and design}

Investigating potential impacts of bilingual practice implemented in an EFL course on learner selfefficacy beliefs, this paper contributes to the scarce classroom-based research on strategic L1 use in L2 teaching. The selection of self-efficacy as the dependent variable appeared to be reasonable given the suggested quality of L1 "as a linguistic resource and a point of reference for learning an L2" (Abrar-ulHassan, 2018, p. 3). The study sought to answer these research questions:

1 Does bilingual practice change the participants' self-efficacy perceptions?

2 How do the participants account for changes in their self-efficacy perceptions?

The findings presented in this paper are an outcome of a broader study which additionally examined the learner perceptions of the bilingual practice through minute papers, course evaluation forms and interviews. The findings were reported in Cabaroğlu and Rathert (2017).

The study employed a single group quasi-experimental design with pre- and post-tests. To triangulate the findings from the self-efficacy scale, interviews were conducted. A convenient sample strategy was employed, i.e. a learner group available for the researchers was chosen for this study. The following subsections provide information about the context, classroom procedures, data collection and analysis.

\subsection{Context}

The study was conducted over a period of 14 weeks in a group of 26 young adult EFL learners (L1: Turkish; mean age: 18.4) in a compulsory English preparatory programme at a Turkish university. The programme prepared learners for their undergraduate programmes with 30 per cent of their subject courses given in English. As documented in English preparatory courses at Turkish universities (BektasCetinkaya \& Oruc, 2010; British Council, 2015), a remarkable part of the students regarded the one- 
year preparatory programme as a lost year, showed indifference towards learning English and displayed disengagement from classroom activities.

The course took 18 hours per week, and a general English coursebook at CEFR level B1+ was used. The first author was the teacher. To minimize threats against research validity, the research purpose and procedures were fully explained to the learners, and the participants were able to withdraw from the study anytime.

The teacher's L1 (German) was neither the learners' L1 nor the target language. Even so an implementation of bilingual activities seemed justified because the teacher had acquired a "working knowledge" (Deller \& Rinvolucri, 2002, passim) of Turkish over a period of 13 years. However, he abstained from activities requiring the "full knowledge" (Deller \& Rinvolucri, 2002, passim) of the learners' L1, that is the proficiency of a native speaker of Turkish.

\subsection{Classroom procedures}

There were 32 instances of strategic and numerous instances of compensatory L1 use (Littlewood \& $\mathrm{Yu}, 2011$ ) during the 14-week course. The activities (ranging from 20 to 60 minutes) were incorporated in the coursebook work. For example, students had to match phrases given in L1 (hemen bir birimize $\imath$ sind $l k$ ) with their equivalents in a coursebook reading text (we hit it off straight away). In another activity, students were dictated sentence beginnings in English containing real conditionals (If you want to find a good job), which they had to translate and write down in L1; they then completed them in L1 and translated them into English. A detailed overview of the activities implemented with samples is given in Cabaroğlu and Rathert (2017, pp. 177-180).

To design, select and implement bilingual activities, criteria were established informed by the related literature (see Section 2.1. and 2.2.; cf. especially Butzkamm \& Caldwell, 2009). They may serve practitioners as guidelines on the implementation of bilingual practice. To be implemented in a lesson, a bilingual activity should meet one or more of the criteria given below. It

- makes use of analogies or associations between L1 and L2

- increases clarity about form and function of structures in case of linguistic dissimilarity between L1 and L2

- helps generate richer content in L2 production by starting from L1

- prevents cognitive overload in L2 reception through recourse to L1

- resembles real world tasks (e.g. translation between residents and tourists)

- reduces the amount of L1 used the longer the activity lasts (i.e. it gradually leads into monolingual practice in L2)

- saves time later available for monolingual practice (e.g. explanation of complex grammar that would be time consuming if entirely given in L2)

- generates a sense of competence and control in learners because resort to L1 is allowed and L2 can be integrated into existing L1 (cf. Brooks-Lewis, 2009).

\subsection{Data collection}

At course beginning and end, the participants were given a 5-point Likert self-efficacy scale of English learning taken from Başaran and Cabaroğlu (2014), developed and used in a preparatory programme at a Turkish university. The 25 items cover self-efficacy concerning motivation and 
expectations, speaking, writing, listening and reading, and the instrument appeared suitable because the bilingual activities covered all language skills.

Six participants were interviewed to triangulate the findings from the self-efficacy scale and to explore their perceptions towards bilingual practice. To select the interviewees, an extreme sampling strategy was applied (Teddlie \& Yu, 2007), i.e. the three students with the highest increase and the three students with the highest decrease in self-efficacy were identified by calculating the absolute difference between the mean values for individual students in pre-test and post-test. Of the 26 participants, 18 participants' self-efficacy levels increased, while eight learners' levels decreased. The interviews were conducted in Turkish, audio-recorded and transcribed for analysis. Interview excerpts used in this paper were translated into English.

\subsection{Data analysis}

Results of both administrations of the self-efficacy were tested for reliability resulting in a Cronbach's alpha coefficient of .832 (pre-test) and .881 (post-test). Due to the small sample size $(\mathrm{N}=26)$, the results were tested for normality of distribution with Shapiro-Wilk test. As the results suggested violation of the assumption of normality for all items, Wilcoxon signed rank test was applied for the comparative analysis. Additionally, we calculated effect size to evaluate the strength of association of the intervention with learner self-efficacy (Cohen, 1988). As suggested by Fritz, Morris and Richler (2012) for nonparametric data, the effect size was determined by calculating the correlation coefficient $r$.

The interview data was analysed in an iterative process taking the research questions into consideration. A re-examination of initial codes helped detect patterns, which were operationally defined as coding categories. The coding categories were finally allocated to themes (Saldana, 2009).

\section{Results}

In the following subsections, the results have been presented. The results concerning self-efficacy have been given for language learning domains separately. The interview results have been organized according to the emerging themes.

\subsection{Self-efficacy scale}

There was no significant difference between the students' perceptions concerning motivation and expectations before and after the course (Table 1). Remarkably, in three of the five items the change was in negative direction (Items 1, 3, 4).

Table 1. Comparison of English self-efficacy perceptions concerning motivation and expectations

\begin{tabular}{lllllllll}
\hline \multicolumn{1}{c}{ ITEMS } & Pair & $N$ & Mean & $S D$ & $Z$ & $p$ & $r$ \\
\hline $\begin{array}{l}\text { I have got a special ability for } \\
\text { learning English. }\end{array}$ & Pre & 26 & 3.35 & 0.94 & & & \\
& & & & & & -.646 & .518 & .09 \\
3 & Post & 26 & 3.23 & 0.82 & & & .14
\end{tabular}


I am sure I can solve any problems I face in learning English.

$4 \quad$ I am satisfied with my current level of English proficiency.

$\begin{array}{ccccccc}\text { Post } & 26 & 4.00 & 0.57 & & & \\ & & & & & & \\ \text { Pre } & 26 & 2.46 & 1.17 & & & \\ & & & & -.364 & .716 & .05 \\ \text { Post } & 26 & 2.35 & 1.02 & & & \\ & & & & & & \\ \text { Pre } & 26 & 4.34 & 0.69 & & & \\ \text { Post } & 26 & 4.38 & 0.70 & & .03 & \\ & & & & & & \\ \text { Pre } & 26 & 4.00 & 1.13 & & & \\ & & & & -.511 & .609 & .07 \\ \text { Post } & 26 & 4.12 & 1.14 & & & \end{array}$

Statistically significant differences in self-efficacy perceptions concerning speaking were detected in challenging tasks (Items 7, 17 and 19) (Table 2). Correlation coefficients show medium effect size indicating that changes in self-efficacy were associated with the bilingual speaking practice.

Table 2. Comparison of English self-efficacy perceptions concerning speaking

\begin{tabular}{|c|c|c|c|c|c|c|c|c|}
\hline & ITEMS & Pair & $N$ & Mean & $S D$ & $Z$ & $p$ & $r$ \\
\hline 2 & $\begin{array}{l}\text { I think that someday I will } \\
\text { speak English very well. }\end{array}$ & $\begin{array}{l}\text { Pre } \\
\text { Post }\end{array}$ & 26 & $\begin{array}{l}3.92 \\
3.69\end{array}$ & $\begin{array}{l}0.98 \\
0.79\end{array}$ & -1.039 & .299 & .14 \\
\hline 7 & $\begin{array}{l}\text { I believe that one day I will } \\
\text { be able to speak English } \\
\text { with American or British } \\
\text { accent. }\end{array}$ & Post & 26 & 3.11 & 0.95 & -2.073 & $.038^{*}$ & .29 \\
\hline 8 & $\begin{array}{l}\text { If I want to say something in } \\
\text { the class, I can say it in } \\
\text { English. }\end{array}$ & Pre & 26 & 3.08 & $\begin{array}{l}0.93 \\
0.90\end{array}$ & -1.520 & .128 & .21 \\
\hline 17 & $\begin{array}{l}\text { I can talk to a foreigner and } \\
\text { introduce myself. }\end{array}$ & $\begin{array}{l}\text { Pre } \\
\text { Post }\end{array}$ & 26 & $\begin{array}{l}4.12 \\
4.46\end{array}$ & $\begin{array}{l}0.77 \\
0.58\end{array}$ & -2.124 & $.034^{*}$ & .29 \\
\hline 19 & $\begin{array}{l}\text { If a foreigner asks a } \\
\text { question, I can reply in } \\
\text { English. }\end{array}$ & Pre & 26 & 2.46 & $\begin{array}{l}0.86 \\
1.00\end{array}$ & -2.289 & $.022 *$ & .32 \\
\hline 23 & $\begin{array}{l}\text { I can introduce me and my } \\
\text { family in English. }\end{array}$ & $\begin{array}{l}\text { Pre } \\
\text { Post }\end{array}$ & 26 & 4.54 & 0.51 & -.632 & .527 & .09 \\
\hline
\end{tabular}

${ }^{*} p$ is significant at the .05 level. 
Table 3 reveals that the learners' beliefs in succeeding more challenging writing tasks (Items 11 and 13) changed significantly with moderate effect size. Also for the other items, a change in the positive direction was ascertained.

Table 3. Comparison of English self-efficacy perceptions concerning writing

\begin{tabular}{|c|c|c|c|c|c|c|c|c|}
\hline \multicolumn{2}{|c|}{ ITEMS } & \multirow{2}{*}{$\begin{array}{l}\text { Pair } \\
\text { Pre }\end{array}$} & \multirow{2}{*}{$\begin{array}{r}N \\
26\end{array}$} & \multirow{2}{*}{$\begin{array}{l}\text { Mean } \\
2.96\end{array}$} & \multirow{2}{*}{$\begin{array}{r}S D \\
0.77\end{array}$} & \multirow{3}{*}{$\begin{array}{c}Z \\
-2.568\end{array}$} & \multirow{3}{*}{$\begin{array}{c}p \\
.010^{*}\end{array}$} & \multirow{3}{*}{$\begin{array}{c}r \\
.36\end{array}$} \\
\hline 11 & I can write about an event that & & & & & & & \\
\hline & I have experienced. & Post & 26 & 3.50 & 0.81 & & & \\
\hline \multirow[t]{2}{*}{13} & I am very confident about & Pre & 26 & 2.08 & 0.84 & \multirow[b]{2}{*}{-1.968} & \multirow[b]{2}{*}{$.049 *$} & \multirow[b]{2}{*}{.27} \\
\hline & $\begin{array}{l}\text { writing in English; I can write } \\
\text { long and detailed passages. }\end{array}$ & Post & 26 & 2.42 & 0.81 & & & \\
\hline \multirow[t]{2}{*}{16} & If I had a pen pal, I could & Pre & 26 & 4.35 & 0.69 & \multirow[b]{2}{*}{-.632} & \multirow[b]{2}{*}{.527} & \multirow[b]{2}{*}{.09} \\
\hline & $\begin{array}{l}\text { write him/her a short letter } \\
\text { and introduce myself. }\end{array}$ & Post & 26 & 4.42 & 0.64 & & & \\
\hline \multirow[t]{2}{*}{21} & I can do written chat with & Pre & 26 & 3.23 & 0.99 & \multirow{2}{*}{-.812} & \multirow{2}{*}{.417} & \multirow{2}{*}{.11} \\
\hline & foreigners. & Post & 26 & 3.42 & 0.86 & & & \\
\hline \multirow[t]{2}{*}{24} & If the teacher says a sentence & Pre & 26 & 3.61 & 0.90 & \multirow[b]{2}{*}{.000} & \multirow[b]{2}{*}{1.000} & \multirow[b]{2}{*}{.000} \\
\hline & $\begin{array}{l}\text { in English, I can write it } \\
\text { correctly. }\end{array}$ & Post & 26 & 3.62 & 0.85 & & & \\
\hline
\end{tabular}

*p is significant at the .05 level.

There were no significant changes in the learners' self-efficacy perceptions concerning reading (Table 4). While the learners' beliefs in the capability to read and understand simple dialogues slightly decreased at a high level (Item 22), the other changes were in positive direction.

Table 4. Comparison of English self-efficacy perceptions concerning reading

\begin{tabular}{|c|c|c|c|c|c|c|c|c|}
\hline \multicolumn{2}{|c|}{ ITEMS } & \multirow{2}{*}{$\begin{array}{l}\text { Pair } \\
\text { Pre }\end{array}$} & \multirow{2}{*}{$\begin{array}{r}N \\
26\end{array}$} & \multirow{2}{*}{$\begin{array}{l}\text { Mean } \\
2.31\end{array}$} & \multirow{2}{*}{$\begin{array}{l}S D \\
0.79\end{array}$} & \multirow{2}{*}{$\begin{array}{c}Z \\
-1.057\end{array}$} & \multirow{2}{*}{$\begin{array}{c}p \\
.290\end{array}$} & \multirow{2}{*}{$\begin{array}{c}r \\
.15\end{array}$} \\
\hline 9 & $\begin{array}{l}\text { I can read and understand } \\
\text { advanced level stories. }\end{array}$ & & & & & & & \\
\hline & & Post & 26 & 2.50 & 0.95 & & & \\
\hline \multirow[t]{2}{*}{14} & I can read and understand & Pre & 26 & 4.04 & 0.72 & \multirow[b]{2}{*}{-1.300} & \multirow[b]{2}{*}{.194} & \multirow[b]{2}{*}{.18} \\
\hline & easy stories. & Post & 26 & 4.19 & 0.40 & & & \\
\hline \multirow[t]{2}{*}{18} & $\begin{array}{l}\text { I can read and understand } \\
\text { unabridged English texts and }\end{array}$ & Pre & 26 & 2.88 & 0.91 & \multirow{2}{*}{-.138} & \multirow{2}{*}{.890} & \multirow{2}{*}{.02} \\
\hline & newspaper columns. & Post & 26 & 2.88 & 1.03 & & & \\
\hline \multirow[t]{2}{*}{22} & I can read and understand & Pre & 26 & 4.42 & 0.58 & \multirow{2}{*}{-.277} & \multirow{2}{*}{.782} & \multirow{2}{*}{.04} \\
\hline & & Post & 26 & 4.38 & 0.50 & & & \\
\hline
\end{tabular}


There were no significant changes in self-efficacy perceptions concerning listening (Table 5). Except for Item 10, the changes were in the positive direction. Compared to the other domains, the scores for listening were rather low in pre-test and post-test.

Table 5. Comparison of English self-efficacy perceptions concerning listening

\begin{tabular}{|c|c|c|c|c|c|c|c|c|}
\hline \multicolumn{2}{|c|}{ ITEMS } & \multirow{2}{*}{$\begin{array}{l}\text { Pair } \\
\text { Pre }\end{array}$} & \multirow{2}{*}{$\begin{array}{c}N \\
26\end{array}$} & \multirow{2}{*}{$\begin{array}{l}\text { Mean } \\
3.23\end{array}$} & \multirow{2}{*}{$\begin{array}{r}S D \\
0.91\end{array}$} & \multirow{3}{*}{$\begin{array}{c}Z \\
-1.000\end{array}$} & \multirow{3}{*}{$\begin{array}{c}p \\
0.317\end{array}$} & \multirow{3}{*}{$\begin{array}{c}r \\
\\
.14\end{array}$} \\
\hline 10 & $\begin{array}{l}\text { If an American or British } \\
\text { person speaks to me, I can }\end{array}$ & & & & & & & \\
\hline & understand him/her easily. & Post & 26 & 3.08 & 0.74 & & & \\
\hline \multirow[t]{2}{*}{12} & When I listen to an English & Pre & 26 & 2.65 & 0.80 & \multirow[b]{2}{*}{-1.387} & \multirow[b]{2}{*}{0.165} & \multirow[b]{2}{*}{.19} \\
\hline & $\begin{array}{l}\text { song, I can understand it } \\
\text { easily. }\end{array}$ & Post & 26 & 2.88 & 0.86 & & & \\
\hline \multirow[t]{2}{*}{15} & & Pre & 26 & 3.46 & 1.03 & \multirow[b]{2}{*}{-1.321} & \multirow[b]{2}{*}{0.186} & \multirow[b]{2}{*}{.14} \\
\hline & $\begin{array}{l}\text { English in the class, I can } \\
\text { understand him/her easily. }\end{array}$ & Post & 26 & 3.69 & 0.74 & & & \\
\hline \multirow[t]{2}{*}{20} & $\begin{array}{l}\text { I can understand English } \\
\text { movies and TV series easily. }\end{array}$ & Pre & 26 & 2.50 & 0.71 & \multirow{2}{*}{-1.500} & \multirow[t]{2}{*}{0.134} & \multirow[t]{2}{*}{.21} \\
\hline & & Post & 26 & 2.73 & 0.78 & & & \\
\hline \multirow[t]{2}{*}{25} & $\begin{array}{l}\text { I can understand English news } \\
\text { programs easily. }\end{array}$ & Pre & 26 & 2.35 & 0.69 & \multirow[t]{2}{*}{-1.696} & \multirow[t]{2}{*}{0.090} & \multirow[t]{2}{*}{.24} \\
\hline & & Post & 26 & 2.69 & 0.68 & & & \\
\hline
\end{tabular}

\subsection{Interviews}

The interviewees associated changes in their self-efficacy with issues which were allocated to five themes: bilingual practice, progress/failure, importance of L2/uncertainty, unwillingness and other classroom practice. That two of the themes were dichotomies is not surprising as the interviewees were extreme cases (Interviewee 1, 2 and 3 with the highest increase in self-efficacy, 4, 5 and 6 with the highest decrease).

Two of the students whose self-efficacy perceptions enhanced associated the increase with the bilingual practice. Interviewee 3 did not initially refer to the bilingual practice, but supposed on enquiry that the activities affected her responses in the second administration of the self-efficacy scale. Notably, participants, irrespective of increased or decreased self-efficacy, pointed to the nature of bilingual practice as activating due to enhanced comprehension:

I learned English better because they [bilingual activities] provided for my participation (...) At least I know what I was doing (...) I struggled, but if you hadn't had included Turkish, I wouldn't have directed myself to the activity (Interviewee 4).

When for example a teacher speaks completely in English, I don't understand anything and just watch and get sleepy while listening (Interviewee 1).

None of the participants with decrease in self-efficacy perceptions related the decrease to the implementation of bilingual practice. On the contrary, Interviewee 4, who was most of the class time off task, said that the inclusion of bilingual techniques came too late for him: 
If Turkish had been used and we had understood what we were going to do from the beginning, I believe I would have done better.

According to Interviewee 6, bilingual practice bridges the gap between Turkish and English. It helped him contrast the languages, triggered greater participation in class and enhanced self-confidence:

They are languages of different geographies (...) they are very distant, but when we see Turkish phrases and translate them into English, we get more self-confident. (...) And when both of them are next to each other, I think I learn better and get more willing. (...) The Turkish especially increased our self-confidence. It is as if we are in our own country.

While Interviewees 1 and 3 related the perception of progress in their own proficiency throughout the course to the increase in self-efficacy, Interviewee 4 related decrease to the feeling of failure. His explanations revealed that he was in a vicious circle as the feeling of failure caused disengagement from learning activities, which in turn reinforced the feeling of failure.

Interviewee 3 reasoned that her awareness of the importance of L2 learning interacted with her improved self-efficacy. She regarded L2 learning contributing to her own personality and as a vehicle to enhance employment prospects:

You have to know the language. You know, we have a proverb: "If you speak one language you have one personality, but if you speak two languages, you have two personalities". (...) If I want to apply for a job in a private company, then English will be absolutely necessary. (...) It's a must because our era is developing so fast.

On the other hand, Interviewee 5 was not able to attach meaning to her learning of English stating that she was not sure at the beginning of the term

if the English classes would be enjoyable or not, if I would want to learn or not.

Unwillingness was explicitly stated by two interviewees with decreased self-efficacy and also frequently expressed by participants throughout the study:

You have to wish to learn the language. I came unwillingly and didn't want to attend the prep classes. (...) I explain the results [of the self-efficacy scale] with my unwillingness (Interviewee 5).

Finally, two participants related enhanced self-efficacy to other classroom practice. Interviewee 1 stated that more careful coursebook work had been conducted than in the previous term, while Interviewee 2 stated that the teacher had provided sufficient wait-time and occasions to work independently.

\section{Discussion}

This study explored the impacts of bilingual practice on EFL learners' English self-efficacy beliefs. The results revealed that self-efficacy beliefs changed significantly for five items related to productive skills. The results also suggest that bilingual practice had a stronger impact on beliefs concerning challenging tasks. The findings from the semi-structured interviews indicate that positive changes in self-efficacy of individual learners were not entirely associated with the bilingual practice, and it was perceived as fostering confidence by learners with diminished self-efficacy.

The impact on writing and speaking skills is in accord to the learners' perceptions of bilingual practice as conducive to language production rather than reception (Cabaroğlu \& Rathert, 2017). The findings also conform to other studies reporting impacts of instructional modification on part of selfefficacy beliefs (e. g. Mills \& Péron, 2009; Yang \& Wang, 2015). In the current study, the bilingual 
practice was implemented into a set of other, monolingual, classroom procedures, i.e. the instructional practice was located halfway in Anderson's (2018) continuum locating L2 instruction as delivered between the poles of monolingual and highly translingual practices. Thus, the participants may not have perceived the bilingual practice as the central teaching/learning tool as, for example, the participants perceived the podcast application in the study by Başaran and Cabaroğlu (2014) reporting significant changes of self-efficacy perceptions in nearly all domains. Moderate effect size values for the statistically significantly changed beliefs furthermore support this interpretation. It should be noted that large effects are not usually expected in educational research given that a number of potential factors are at play (Lenhard \& Lenhard, 2016). From a more general perspective, the results confirm that selfefficacy changes do not occur easily within a short time (Bandura 1997), which was 14 weeks in this study.

Similar to Piniel and Csizér (2015), the results coming from the quantitative and qualitative data are somehow discrepant since also learners with diminished self-efficacy evaluated the bilingual practice as a positive learning experience. In other words, evidence for further strengthened self-efficacy could have been expected in the quantitative data. The interviews, however, strongly suggest that positive effects of the bilingual practice were overshadowed by the problematic EFL context of preparatory programmes (British Council, 2015). Although the learners welcomed L1 inclusion, the bilingual practice was no remedy for the apparent unwillingness and indifference of the learners as the meaningfulness of learning English was called into question. This explanation coincides with the results of three out of five items concerning motivation and expectations in the scale changing slightly in negative direction. Notably, learners with decreased self-efficacy reported that the bilingual practice came too late for them, and they appraised the bilingual practice as a way to "deforeignise the foreign" (Butzkamm \& Caldwell, 2009, p. 92) claiming it enhanced comprehension because they could connect L2 to L1.

\section{Conclusions}

While this study was conducted in Turkey, the results are potentially relevant to EFL classrooms elsewhere characterized by similar circumstances. For one thing, teachers may allow learners starting from L1 as a preparation for language production. In addition, more than the quantitative data, the interviews suggest that an implementation of bilingual practice may be a vehicle to encourage weaker learners to participate more fully in lessons, i.e. bilingual practice serves as a tool in differentiated instruction. Practitioners, however, should consider that other factors are likely to interfere with effects of bilingual practice (Kormos, Kiddle \& Csizér, 2011), and decisions on how to incorporate bilingual practice need to be informed by the specific teaching context (Kerr, 2015).

A further conclusion drawn from this study refers to the need to triangulate results from quantitative instruments with data received from other instruments (e.g. interviews) when investigating effects of instructional modification on self-efficacy. Reliance on quantitative data may be misleading as factors changing learner beliefs remain unnoticed.

The limited number of participants, the specific context and the restricted duration surely limit this study. Specifically, comparison of instruction with and without bilingual practice using a control group design, which was not feasible in the current study, is desirable to generate more context-dependent knowledge on the value of bilingual practice. 


\section{Ethics Committee Approval}

The author(s) confirm(s) that the study does not need ethics committee approval according to the research integrity rules in their country (Date of Confirmation: June 01, 2020).

\section{References}

Abrar-ul-Hassan, S. (2018). Motivational strategies. In J. I. Liontas, T. International Association, \& M. DelliCarpini (Eds.), The TESOL Encyclopedia of English Language Teaching ( $1^{\text {st }}$ ed.). doi:10.1002/9781118784235.eelt0178.

Alegria de la Colina, A., \& García Mayo, M. P. (2009). Oral instruction in task-based EFL learning: The use of L1 as a cognitive tool. International Review of Applied Linguistics in Language Teaching, $47,325-345$.

Alishah, A. R., \& Dolmaci, M. (2013). The interface between self-efficacy concerning the selfassessment on students studying English as a foreign language. Procedia - Social and Behavioral Sciences, 70, 873-881.

Ammar, A., Lightbown, P. M., \& Spada, N. (2010). Awareness of L1/L2 differences: does it matter? Language Awareness, 1(2), 129-146.

Anderson, J. (2018). Reimagining English language learners from a translingual perspective. English Language Teaching Journal, 72(1), 26-37.

Anton, M., \& DiCamilla, F. J. (1999). Socio-cognitive functions of L1 collaborative interaction in the L2 classroom. The Modern Language Journal, 83(2), 233-247.

Auerbach, E. R. (1993). Reexamining English only in the ESL classroom. TESOL Quarterly, 27(1), 932.

Augustyn, P. (2013). No dictionaries in the classroom: translation equivalents and vocabulary acquisition. International Journal of Lexicography, 26, 362-385.

Balci, O. (2017). The effects of learning-style based activities on students' reading comprehension skills and self-efficacy perceptions in English foreign language classes. Higher Education Studies, 7(4), $35-54$.

Baleghizadeh, S., \& Masoun, A. (2013). The effect of self-assessment on EFL learners' self-efficacy. TESL Canada Journal, 31(1), 42-58.

Bandura, A. (1986). Social foundations of thought and action: A social cognitive theory. Englewood Cliffs, NJ: Prentice Hall.

Bandura, A. (1997). Self-efficacy: The exercise of control. New York: Freeman.

Bandura, A. (2001). Social cognitive theory: An agentic perspective. Annual Review of Psychology, 52, $1-26$.

Başaran, S., \& Cabaroğlu, N. (2014). The effect of language learning podcasts on English self-efficacy. International Journal of Language Academy, 2(2), 48-69.

Bektas-Cetinkaya, Y., \& Oruc, N. (2010). Turkish students' motivation to learn English at public and private universities. Procedia Social and Behavioral Sciences 2, 4662-4666.

British Council. (2015). The state of English in higher education in Turkey. Ankara: Yorum Basin Yayın Sanayi. 
Brooks-Lewis, K. A. (2009). Adult learners' perceptions of the incorporation of their L1 in foreign language teaching and learning. Applied Linguistics, 30(2), 216-235.

Bruen, J., \& Kelly, N. (2017). Using a shared L1 to reduce cognitive overload and anxiety levels in the L2 classroom. The Language Learning Journal, 45(3), 368-381.

Butzkamm, W. (2001). Learning the language of the loved ones: on the generative principle and the technique of mirroring. English Language Teaching Journal, 55(2), 149-154.

Butzkamm, W., \& Caldwell, J. A. W. (2009). The bilingual reform. A paradigm shift in foreign language teaching. Tübingen: Gunter Narr.

Cabaroğlu, N., \& Rathert, S. (2017). Learner perceptions of an inclusion of bilingual activities to teach English as a foreign language. International Journal of Language Academy, 5(7), 160-180.

Canagarajah, S. (2018). Translingual practice as spatial repertoires: expanding the paradigm beyond structuralist orientations. Applied Linguistics, 39(1), 31-54.

Cave, P. N., Evans, N. W., Dewey, D. P., \& Hartshorn, K. J. (2018). Motivational partnerships: increasing ESL student self-efficacy. English Language Teaching Journal, 72(1), 83-96.

Ching, L. C. (2002). Strategy and self-regulation instruction as contributors to improving students' cognitive model in an ESL program. English for Specific Purposes, 21(3), 261-289.

Chularut, P., \& DeBacker, T. (2004). The influence of concept mapping on achievement, self-regulation, and self-efficacy in students of English as a second language. Contemporary Educational Psychology, 29(3), 248-263.

Cohen, A. C. (2015). Achieving academic control in two languages: Drawing on the psychology of language learning in considering the past, the present, and prospects for the future. Studies in Second Language Learning and Teaching, 5(2), 327-345.

Cohen, J. (1988). Statistical power analysis for the behavioural sciences $\left(2^{\text {nd }}\right.$ ed.). Hillsdale: NJ: Erlbaum.

Cook, G. (2010). Translation in language teaching. Oxford: Oxford University Press.

Cook, G. (2018). Learning through translation. In Burns, A. \& J. R. Richards (Eds.), The Cambridge guide to learning English as a second language (pp. 289-297). Cambridge: Cambridge University Press.

Cook, V. (2010). The relation between first and second language acquisition revisited. In: E. Macaro (Ed.), Continuum companion to second language acquisition (pp. 137-157). Continuum International Publishing Group: London, New York.

Corcoll López, C., \& González-Davies, M. (2016). Switching codes in the plurilingual classroom. English Language Teaching Journal, 70(1), 67-77.

Council of Europe. (2001). Common European Framework of Reference for Languages: Learning, teaching, assessment. Cambridge: Cambridge University Press.

Cummins, J. (2017). Teaching for transfer in multilingual school contexts. In O. Garcia, A. M. Y. Lin, \& S. May (Eds.), Bilingual and multilingual education ( $3^{\text {rd }}$ ed.) (pp. 103-115). Cham: Springer.

Deller, S., \& Rinvolucri, M., (2002). Using the mother tongue. Making the most of the learner's language. Surrey: Delta Publishing. 
DiCamilla, F. J., \& Anton, M. (2012). Functions of L1 in the collaborative interaction of beginning and advanced second language learners. International Journal of Applied Linguistics, 22(2), 160-188.

Ellis, R., \& Shintani, N. (2014). Exploring language pedagogy through second language acquisition research. Abingdon: Routledge.

Fritz, C. O., Morris, P. E., \& Richler, J. L. (2012). Effect size estimates: Current use, calculation and interpretation. Journal of Experimental Psychology: General, 141(1), 2-18.

Ganem-Gutierrez, G. A., \& Roehr, K. (2011). Use of L1, metalanguage, and discourse markers: L2 learners' regulation during individual task performance. International Journal of Applied Linguistics, 21(3), 297-318.

Garcia, O. (2009). Education, multilingualism and translanguaging in the $21^{\text {st }}$ century. In T. SkutnabbKangas, R. Philippson, A. K. Mohanty, \& M. Panda (Eds.), Social justice through multilingual education (pp. 140-158). Bristol: Multilingual Matters.

Gonzalez Davies, M. (2004) Multiple voices in the translation classroom. Amsterdam/Philadelphia: John Benjamins.

Graham, S. (2007). Learner strategies and self-efficacy: making the connection. Language Learning Journal, 35(1), 81-93.

Graham, S., \& Macaro, E. (2008). Strategy instruction in listening for lower-intermediate learners of French. Language Learning, 58(4), 747-783.

Hall, G. \& Cook, G. (2012). Own-language use in language teaching and learning. Language Teaching, 45, 271-308.

Hall, G., \& Cook, G. (2013). Own-language use in ELT: exploring global practices and attitudes. (ELT Research Papers 13-01). London: British Council.

He, A. E. (2012). Systematic use of mother tongue as learning/teaching resources in target language instruction. Multilingual Education, 2(1), 1-15.

Henderson, M., Huang, H., Grant, S., \& Henderson, L. (2012). The impact of Chinese language lessons in a virtual world on university students' self-efficacy beliefs. Australian Journal of Educational Technology 28(3), 400-419.

Huang, C.-T., \& Yang, S. C. (2015). Effects of online reciprocal teaching on reading strategies, comprehension, self-efficacy and motivation. Journal of Educational Computing Research, 52(3), 381-407.

Kelly, N., \& Bruen, J. (2015). Translation as a pedagogical tool in the foreign language classroom: A qualitative study of attitudes and behaviours. Language Teaching Research, 19(2), 150-168.

Kerr, P. (2014). Translation and own-language activities. Cambridge: Cambridge University Press.

Kerr, P. (2015). The learner's own language. Exploration in English Language and Linguistics, 3(1), 17.

Keller, J. M. (1979). Motivation and instructional design: a theoretical perspective. Journal of Instructional Development, 2(4), 26-34.

Khajavi, Y., \& Ketabi, S. (2012). Influencing EFL learners' reading comprehension and self-efficacy beliefs: The effect of concept mapping strategy. Porta Linguarum, 17, 9-27. 
Kim, E.-Y. (2011). Using translation exercises in the communicative EFL writing classroom. English Language Teaching Journal, 65(2), 154-160.

Kormos, J., Kiddle, T., \& Csizér, K. (2011). Systems of goals, attitudes and self-related beliefs in second-language-learning motivation. Applied Linguistics, 32(5), 495-516.

Kupferberg, I. (1999). The cognitive turn of contrastive analysis: Empirical evidence. Language Awareness, 8(3-4), 210-222.

Kupferberg, I., \& Olshtain, E. (1996). Explicit contrastive instruction facilitates the acquisition of difficult L2 forms. Language Awareness, 3(4), 149-165.

Laufer, B., \& Girsai, N. (2008). Form-focused instruction in second language vocabulary learning: a case for contrastive analysis and translation. Applied Linguistics, 29(4), 694-716.

Laviosa, S. (2014). Translation and language education. Abingdon: Routledge.

Lee, M. W. (2018). Translation revisited for low-proficiency EFL writers. English Language Teaching Journal 72(4), 365-373.

Lenhard, W., \& Lenhard, A. (2016). Calculation of effect sizes. Dettelbach (Germany): Psychometrica. DOI: 10.13140/RG.2.1.3478.4245 (Retrieved 29 January 2017 from: https://www.psychometrica.de/effect_size.html).

Leonardi, V. (2010). The role of pedagogical translation in second language acquisition. From theory to practice. Bern: Peter Lang.

Levine, G. S. (2013). The case for a multilingual approach to language classroom communication'. Language and Linguistics Compass, 7(8), 423-436.

Littlewood, W., \& Yu, B. (2011). First language and target language in the foreign language classroom. Language Teaching, 44(1), 64-77.

Macaro, E. (2005). Codeswitching in the L2 classroom: A communication and learning strategy. In E. Llurda (Ed.), Non-native language teachers. Perceptions, challenges and contributions to the profession. (Educational Linguistics Vol. 2), (pp. 63-84). Boston, MA: Springer.

Macaro, E, Nakatani, Y, Hayashi, Y., \& Khabbazbashi, N. (2014). Exploring the value of bilingual language assistants with Japanese English as a foreign language learners. The Language Learning Journal, 42(1), 41-54.

Mahboob, A., \& Lin, A. M. Y. (2016). Using local languages in English language classrooms. In W. A. Renyanda \& H. P. Widodo (Eds.) English language teaching today (pp. 25-40). Cham: Springer.

Martínez, R. A., Hikida, M., \& Durán, L. (2015). Unpacking ideologies of linguistic purism: How Dual language teachers make sense of everyday translanguaging, International Multilingual Research Journal, 9(1), 26-42.

May, S. (2014). Disciplinary divides, knowledge construction, and the multilingual turn, In S. May (Ed.), The multilingual turn: implications for SLA, TESOL and bilingual education (pp. 7-31). New York: Routledge.

Meier, G. S. (2017). The multilingual turn as a critical movement in education: assumptions, challenges and a need for reflection. Applied Linguistics Review 8(1), 131-161.

Mills, N. (2014). Self-efficacy in second language acquisition. In S. Mercer \& M. Williams (Eds.), Multiple perspectives on the self in SLA (pp. 6-22). Bristol: Multilingual Matters. 
Mills, N. A. (2009). A 'Guide du Routard' simulation: enhancing the standards through project-based learning. Foreign Language Annals 42(4), 607-639.

Mills, N., Pajares, F., \& Herron, C. (2006). A reevaluation of the role of anxiety: Self-efficacy, anxiety, and their relation to reading and listening proficiency. Foreign Language Annals, 39(2), 276-295.

Mills, N. A., \& Péron, M. (2009). Global simulation and writing self-beliefs of college intermediate French students. International Journal of Applied Linguistics, 156, 239-273.

Moore, P. (2018). Becoming bilingual in the EFL classroom. English Language Teaching Journal, 72(2), 131-140.

Moore, P. J. (2013). An emergent perspective on the use of the first language in the English-as-a-foreignlanguage classroom. The Modern Language Journal, 97(1), 239-253.

Moreno, R., \& Kilpatrck, J. (2018). Student perceptions of self-efficacy in the foreign language classroom: A design-based research study. Educational Design Research, 2(1), 1-26.

Neokleous, G. (2017). Closing the gap: student attitudes toward first language use in monolingual EFL classrooms. TESOL Journal, (8)2, 314-341.

Oghyanous, P. A. (2017). The effect of brain-based teaching on young EFL learners' self efficacy. English Language Teaching, 10(5), 158-166.

Pajares, F. (2002). Gender and perceived self-efficacy in self-regulated learning. Theory into Practice, $41(2), 116-125$.

Pan, C.-Y., \& Wu, H.-Y. (2013). The cooperative learning effects on English reading comprehension and learning motivation on EFL freshman. English Language Teaching, 6(5), 13-27.

Paquet-Gauthier, M., \& Beaulieu, S. (2016). Can language classrooms take the multilingual turn? Journal of Multilingual and Multicultural Development, 37(2), 167-183.

Piniel, K. \& Csizér, K. (2015). Changes in motivation, anxiety and self-efficacy during the course of an academic writing seminar. In Z. Dörniyei, P. D. MacIntyre, \& A. Henry (Eds.), Motivational dynamics in language teaching (pp. 164-194). Bristol: Multilingual Matters.

Rachels, J. R., \& Rockinson-Szapkiw, A. J. (2018). The effects of a mobile gamification app on elementary students' Spanish achievement and self-efficacy. Computer Assisted Language Learning, 31(1-2), 72-89.

Rahimirad, M., \& Zare-ee, A. (2015). Metacognitive strategy instruction as a means to improve listening self-efficacy among Iranian Undergraduate learners of English. International Journal of Instruction, $8(1), 117-132$.

Rivers, D. J., \& Ross, S. R. (2018). L1/L2 communication self-efficacy beliefs and the contribution of personality. The Language Learning Journal. Advanced online publication.

Ruegg, R. (2018). The effect of peer and teacher feedback on changes in EFL students' writing selfefficacy. The Language Learning Journal, 46(2), 87-102.

Saldana, J. (2009). The coding manual for qualitative researchers. Los Angelas, CA: Sage.

Scheffler, P., Horverak, M. O., Krzebietke, W., \& Askland, S. (2017). Language background and learners' attitudes to own language use. English Language Teaching Journal, 71(2), 197-217.

Scida, E. E., \& Jones, J. N. (2017). The impact of contemplative practices on foreign language anxiety and learning. Studies in Second Language Learning and Teaching, 7(4), 573-599. 
Swain, M., \& Lapkin, S. (2000). Task-based second language learning: the uses of the first language. Language Teaching Research, 4(3), 251-274.

Tai, H.-C. (2016). Effects of collaborative online learning on EFL learners' writing performance and self-efficacy. English Language Teaching, 9(5), 119-133.

Taki, S., \& Esmaeili, Z. (2017). Shadowing and EFL listening comprehension: Focus on metacognitive strategy use, self-efficacy and achievement. The Journal of Teaching English for Specific and Academic Purposes, 5(4), 727-738.

Teddlie, C., \& Yu, F. (2007). Mixed methods sampling. A typology with examples. Journal of Mixed Methods Research, 1(1), 77-100.

Tian, L., \& Macaro, E. (2012). Comparing the effect of teacher codeswitching with English-only explanation on the vocabulary acquisition of Chinese university students: A lexical focus-on form study. Language Teaching Research, 16, 361-385.

Turnbull, B. (2016). Reframing foreign language learning as bilingual education: Epistemological changes towards the emergent bilingual. International Journal of Bilingual Education and Bilingualism, 1-8. doi: 10.1080/13670050.2016.1238866.

Wang, D. (2016). Translanguaging in Chinese foreign language classrooms: students and teachers' attitudes and practices. International Journal of Bilingual Education and Bilingualism, DOI: 10.1080/13670050.2016.1231773.

Xu, Y., Park, H., \& Baek, Y. (2011). A new approach toward digital storytelling: an activity focused on writing self-efficacy in a virtual learning environment. Educational Technology \& Society, 14(4), $181-191$.

Yang, P.-L., \& Wang, A.-L. (2015). Investigating the relationship among language learning strategies, English self-efficacy, and explicit strategy instructions. Taiwan Journal of TESOL, 12(1), 35-62.

Yang, X. Guo, X., \& Yu, S. (2016). Effects of cooperative translation on Chinese EFL student levels of interest and self-efficacy in specialized English translation. Computer Assisted Language Learning, 29(3), 477-493.

Zheng, D., Young, M. F., Brewer, R. A., \& Wagner, M. (2009). Attitude and self-efficacy change: English language learning in virtual worlds. CALICO Journal, 27(1), 205-231.

Ziegler, G., Sert, O., \& Durus, N. (2012). Student-initiated use of multilingual resources in Englishlanguage classroom interaction: next-turn management. Classroom Discourse, 3(2), 187-204. 


\section{Çift dilli uygulamaların İngilizceyi yabancı dil olarak öğrenen öğrencilerin özyeterlilikleri üzerine etkisi}

\section{$\ddot{O} z$}

Yabancı dil öğretimi sırasında öğrencilerin ana dilinin kullanımı giderek önem kazanmaktadır. Buradan yola çıkarak bu çalışmada, Türkiye'deki bir üniversitede İngilizceyi yabancı dil olarak öğrenen 26 genç-yetişkin öğrenciye ölçüt dayanaklı çift dilli İngilizce öğretimi üzerine yapılan bir araştırmanın sonuçları paylaşılmıştır.

Çift dil kullanarak yabancı dil öğretiminin öğrencilerin özyeterlilikleri üzerine olası etkilerini belirlemek için 14 hafta süren bir dersin öncesinde ve sonrasında öğrencilere İngilizce özyeterlilik ölçeği verilmiştir. Ayrıca ölçekten elde edilen bulgularla veri üçlemesi sağlamak amacıyla katılımcılarla görüşmeler yapılmıştır. Elde edilen bulgular, çift dilli uygulamalar sonucunda 25 öğrenciden sadece beşinin (konuşma ve yazma becerileriyle ilgili) özyeterlilik algılarında orta derece önemde değişiklik olduğunu göstermiştir. Görüşme yöntemiyle elde edilen bulgular, öğrencilerin özyeterlik algılarındaki değişikliğin çift dilli uygulamalara kısmen dayandırılabileceğini ortaya çıkartmıştır. Ders bağlamındaki kötü koşulların (oldukça fazla sayıda öğrencinin hazırlık okumayı yıl kaybı olarak değerlendirmeleri, İngilizce öğrenmeye ilgisiz kalmaları ve dolayısıyla sınıf içi aktivitelere katılmamaları gibi), çift dilli uygulamalardan beklenen olumlu etkileri gölgede bıraktığını göstermiştir. Çalışmadan elde edilen diğer bir bulgu da, öğrenciler tarafından çift dilli uygulamaların yabancı dil öğrenimine olumlu katkılarda bulunabileceği şeklinde algıladıklarıdır. Çift dilli uygulamaların, özyeterliği düşük öğrencilerin yabancı dil öğrenimiyle ilgili özel gereksinimlerini gidermede yardımcı bir unsur olabileceği de ortaya çıkmıştır.

Anahtar sözcükler: Çift dilli uygulamalar, özyeterlilik, yabancı dil olarak İngilizce, özel öğretim yöntemleri, genç yetişkin öğrenciler

\section{AUTHOR BIODATA}

Stefan Rathert is an assistant professor in the English Language Teaching Department at Kahramanmaraş Sütçü İmam University, Turkey. He received his PhD degree from Çukurova University, Adana, Turkey. His research interests include teaching methodology, materials in language teaching and professional development of language teachers.

Neşe Cabaroğlu is a lecturer in the English Language Teaching Department at Cukurova University, Adana, Turkey. She received a PhD degree from the University of Reading, UK. Her research revolves around issues related to teacher education, teacher cognition, student teacher learning, and professional development. 